\title{
A Comparison of Predatory Behavior of Newly Hatched Rhabdophis tigrinus (Serpentes: Colubridae) on Frogs and Fish
}

\author{
AKIRA MORI
}

\begin{abstract}
Various sizes of frogs and fish were offered in captivity to examine the effects of prey size and type on predatory behavior of newborns of Rhabdophis tigrinus, which has well-developed Duvernoy's glands. Frogs were more easily captured and handled than fish. There were no clear differences in swallowing efficiency between frogs and fish. Relative prey size did not affect direction of ingestion or condition of prey at ingestion in either prey type. Fish, some of which were dead, tended to be swallowed head first, whereas all frogs were swallowed alive without a preference for direction of ingestion. In frogs, direction of ingestion seemed to largely depend on initial bite position. In either prey type, direction of ingestion did not affect swallowing duration. Death of the fish seemed to be related to longer handling duration. Except for the absence of head first ingestion of frogs, neonate $R$. tigrinus seemed to be more efficient in frog handling than fish handling.
\end{abstract}

Key words: Rhabdophis tigrinus; Prey handling behavior; Head first ingestion; Duvernoy's glands; Feeding duration

The Japanese grass snake, Rhabdophis tigrinus, is one of the most common colubrid species in Japan. Field studies have revealed that its diet mostly consists of frogs and toads with an occasional exploitation of fish (Fukada, 1959; Moriguchi, 1982; Moriguchi and Naito, 1982; Kadowaki, 1992). The snake has welldeveloped Duvernoy's glands, and many physiological and toxicological studies have been done on the secretions of the glands [see Toriba and Sawai (1990) for review]. It has been suggested that biological functions of the secretions may be associated with feeding such as incapacitating struggling prey animals (e.g., Moriguchi, 1996). However, quantitative studies of feeding behavior of $R$. tigrinus are meager.

In this paper, prey-handling behavior of neonate $R$. tigrinus was examined using frogs and fish as prey animals. Here, I focused on two aspects of prey-handling methods: direction of prey ingestion and condition of prey at ingestion (alive or dead). The former variable was selected to examine the tendency of head first ingestion of prey, which is a characteristic behavior of many snakes, presumably adapted for ingestion of relatively large prey (Diefenbach and Emslie, 1971; de Queiroz and de Queiroz, 1987). The latter variable was selected to ex-

Accepted 12 Sept. 1997 amine the effect of Duvernoy's gland secretions during handling. Several other behavioral acts and feeding durations were also examined to compare the efficiency of capture and handling between major (frogs) and minor (fish) food items.

\section{Materials and Methods}

The subjects were nine neonate snakes hatched in the laboratory from eggs oviposited by a female collected in Okayama prefecture. Newly hatched snakes were weighed, measured (snoutvent length and head width), and then housed individually in white polypropylene cages $(190 \times 140 \times 70 \mathrm{~mm})$, each containing a water dish and paper floor covering. The temperature varied between 25 and $31^{\circ} \mathrm{C}$. Illumination was provided by sunlight. No food was provided before testing.

Five and four snakes were tested with the Japanese tree frog (Hyla japonica) and goldfish (Carassius auratus), respectively. Eight to 11 trials were made for each snake except one which was tested only five times. A total of 42 and 41 trials were conducted for frogs and fish, respectively. The first trial of each snake was conducted one to two weeks after the first shedding was completed, and the subsequent trials were made with at intervals of basically two or three days. Maximum head width and body mass (BM) of frogs, and maximum body height and 
BM of fish were measured prior to each trial. Prey size relative to snake size was expressed as either the relative prey width (RPW: maximum width of prey/head width of snake) or relative prey mass (RPM : BM of prey/BM of snake).

The testing arena was made of white polypropylene corrugated board (measuring $200 \times 100 \times 100 \mathrm{~mm}$ ) with a transparent plastic cover. The arena was divided into two compartments $(150 \times 100 \times 100 \mathrm{~mm}$ and $50 \times 100 \times 100$ $\mathrm{mm}$ ) by a plastic insert across the floor. For fish trials, a small pool $(100 \times 100 \times 20 \mathrm{~mm})$ filled with water to a depth of $1 \mathrm{~cm}$ was set inside the larger compartment. About $10 \mathrm{~min}$ prior to each trial, a snake and a prey animal were introduced into the smaller and the larger compartments of the arena, respectively. Each trial was initiated by removal of the insert from the arena by sliding it out through a slit in the front wall. After each trial, the arena was washed with water. During the experiments, room temperature varied between 27.0 and $30.5^{\circ} \mathrm{C}$.

All trials were directly observed and recorded with a video camera (National VZ-C70, VHS type) and a video monitor (National NV-8480). Videotapes were analyzed to examine the variables listed below.

The following four variables were counted for each trial. Number of strikes: the number of attempts at capture by striking movements of the snake. Number of failures: the number of strikes which resulted in the unsuccessful capture of prey. Number of escapes: the number of incidences in which the prey, by vigorously struggling, escaped from the grip by the snake during handling or swallowing. Number of releases: the number of incidences in which the snake voluntarily released its grip or dropped the prey during handling.

The following three variables were examined and categorized for each trial. Capture position: the part of the prey's body struck and grasped by the snake; anterior $=$ head and shoulder for frog, and body part anterior to the point of maximum body height for fish; mid$\mathrm{dle}=\mathrm{abdomen}$ and forelegs for frog, and body part posterior to the point of maximum body height excluding tail for fish; posterior $=$ pelvic region and hind legs for frog, and tail for fish. When the prey escaped from the snake's grip and was captured again, capture position was defined as the one which preceded successful swallowing of the prey. Direction of prey ingestion: the prey was eventually swallowed head first or tail (hind legs) first. Condition of prey at ingestion: prey that made any movements, including breathing and gill movements, during swallowing were considered "alive", otherwise "dead".

Two feeding durations were measured. Handling duration: time in seconds from the initial seizure of the prey to the commencement of swallowing. The commencement of swallowing was defined as the first unilateral "walking" movement of the snake's jaw over the body of the prey in the direction in which the prey was subsequently swallowed. Swallowing duration: time in seconds from the commencement of swallowing until the prey was no longer visible.

Mann-Whitney U-tests, binomial tests, Fisher's exact probability tests, and analysis of covariance (ANCOVA) were used for statistical analysis (Siegel and Castellan, 1988; Sokal and Rohlf, 1995). Prior to making ANCOVA, homogeneity of variance was examined, and in all cases this assumption was not rejected at $\mathrm{p}=0.05$. Fisher's exact probability test for $2 \times 3$ table was conducted using the FREQ Procedure of SAS (SAS Institute Inc, 1989). All tests were two-tailed, and the level of significance was $\mathrm{p}=0.05$.

\section{RESULTS}

Preliminary analysis showed that there were no apparent ontogenetic changes throughout the experiment in any behavioral variables recorded. Hence, in the following analyses, effects of time were not considered. For statistical analysis, the data were pooled, tentatively regarding the data from the same individual as independent data.

In 31 cases, the snake successfully captured the frog at the first strike. In the remaining 11 cases, the snake failed to capture the frog one to six times (Table 1). Escape of the frog during handling was observed only on two occasions. No snake voluntarily released or dropped the frog during handling.

The snakes frequently failed to capture the fish and in only five cases successfully captured the fish at the first strike (Table 1). The snakes struck the fish by either an aerial attack or an underwater attack. In nine cases the fish were eventually captured by an aerial attack, and in 30 cases they were captured by underwater attack. In the latter cases, the snakes appeared to rely on chance encounters with prey, which frequently followed underwater open mouth searching (see Drummond, 1983). After the successful grip of the fish, the snake moved onto the land area and commenced to maneuver the fish. The fish escaped from the snake's grip during 
TABLE 1. Comparison of prey capture and handling ability between frogs and fish in feeding tests of neonate Rhabdophis tigrinus. See text for detailed explanation of variables. All variables are significantly larger in fish than in frogs (U-tests, $\mathrm{p}<0.001$ ).

\begin{tabular}{lcccccccc}
\hline & \multicolumn{3}{c}{ Frog $(\mathrm{N}=42)$} & & \multicolumn{3}{c}{ Fish $\left(\mathrm{N}=39^{1)}\right)$} \\
\cline { 2 - 3 } \cline { 7 - 9 } Variables & $\overline{\mathrm{x}}$ & SE & Range & & $\overline{\mathrm{x}}$ & SE & Range \\
\hline No. of attacks & 1.50 & 0.17 & $1-6$ & & 7.41 & 1.10 & $1-35$ \\
No. of failures & 0.45 & 0.16 & $0-6$ & & 5.69 & 1.02 & $0-31$ \\
No. of escapes & 0.05 & 0.03 & $0-1$ & & 0.72 & 0.21 & $0-7$ \\
No. of releases & 0 & 0 & - & & 1.67 & 0.63 & $0-15$ \\
\hline
\end{tabular}

1) Because of a videotape recording error, two trials were not analyzed.

handling in 16 cases. The snake voluntarily released or dropped the fish in 12 cases. The numbers of attacks, failures, escapes, and releases were all significantly higher in fish trials than in frog trials (U-tests; attacks, $z=6.13$, $\mathrm{p}<0.0001$; failures, $\mathrm{z}=5.84, \mathrm{p}<0.001$; escapes, $\mathrm{z}=3.95, \mathrm{p}<0.001$; releases, $\mathrm{z}=3.47, \mathrm{p}<0.001$ ).

There were no significant differences in RPW between the frogs swallowed head first and hind legs first (U-test, $\mathrm{z}=1.11, \mathrm{p}>0.25$; Table 2). Frequency of head first ingestion was not significantly different from random distribution (binomial test, $\mathrm{p}>0.2$ ). There were no significant differences in RPW between the fish swallowed head first and tail first (U-test, $\mathrm{z}=0.59, \mathrm{p}>0.55$ ). More than $80 \%$ of the fish were swallowed head first, which significantly deviated from random distribution (binomial test, $p<0.001)$. The direction of ingestion was significantly related to the initial bite position in frog feeding (Fisher test, $\mathrm{p}<0.001$ : Table 3 ). In fish feeding, direction of ingestion was significantly associated with the initial bite position (Fisher test, $\mathrm{p}<0.001$ ), although some of the fish grasped at the posterior body part eventually were swallowed head first.

TABLE 2. Relationship between direction of ingestion of prey and relative prey width (RPW) in feeding tests of neonate Rhabdophis tigrinus. RPW was calculated as (maximum head width of prey)/(snake head width) and (maximum body height of prey)/ (snake head width) for frogs and fish, respectively.

\begin{tabular}{llrccc}
\hline \multirow{2}{*}{ Prey } & $\begin{array}{l}\text { Direction of } \\
\text { ingestion }\end{array}$ & \multicolumn{4}{c}{ RPW } \\
\cline { 2 - 6 } & F & $\overline{\mathrm{x}}$ & $\mathrm{SE}$ & range \\
\hline \multirow{2}{*}{ Frogs } & Head first & 16 & 1.12 & 0.04 & $0.83-1.48$ \\
& Hind legs first & 25 & 1.17 & 0.04 & $0.84-1.59$ \\
& Head first & 33 & 1.51 & 0.03 & $1.18-1.81$ \\
& Tail first & 8 & 1.43 & 0.07 & $1.15-1.63$ \\
\hline
\end{tabular}

TABLE 3. Relationship between initial bite position and direction of ingestion of prey in feeding tests of neonate Rhabdophis tigrinus with frogs and fish as prey animals. $\mathbf{A}=$ anterior, $\mathbf{M}=$ middle, $\mathbf{P}=$ posterior. See text for detailed definition of bite positions.

\begin{tabular}{|c|c|c|c|c|c|c|}
\hline \multirow{2}{*}{$\begin{array}{l}\text { Direction of } \\
\text { ingestion }\end{array}$} & \multicolumn{3}{|c|}{ Frogs bite position } & \multicolumn{3}{|c|}{ Fish bite position } \\
\hline & $\mathbf{A}$ & $\mathbf{M}$ & $\mathbf{P}$ & A & $\mathbf{M}$ & $\mathbf{P}$ \\
\hline Head first & 8 & 8 & 0 & 19 & 9 & 3 \\
\hline Hind legs (tail) firs & st 1 & 2 & 22 & 0 & 3 & 5 \\
\hline
\end{tabular}

In frog trials, swallowing duration was significantly correlated with RPW both in head first and hind legs first ingestions (head first, $\mathrm{r}=0.83, \mathrm{df}=13, \mathrm{t}=5.39, \mathrm{p}<0.001$; hind legs, $\mathrm{r}=0.66, \mathrm{df}=22, \mathrm{t}=4.14, \mathrm{p}<0.001 ;$ Fig. 1). There were no significant differences in either slopes or elevations between direction of ingestion of frogs (ANCOVA; slopes, $\mathrm{dF}=1,35$, $\mathrm{F}=0.001, \mathrm{p}>0.95 ;$ elevations, $\mathrm{dF}=1,36$,
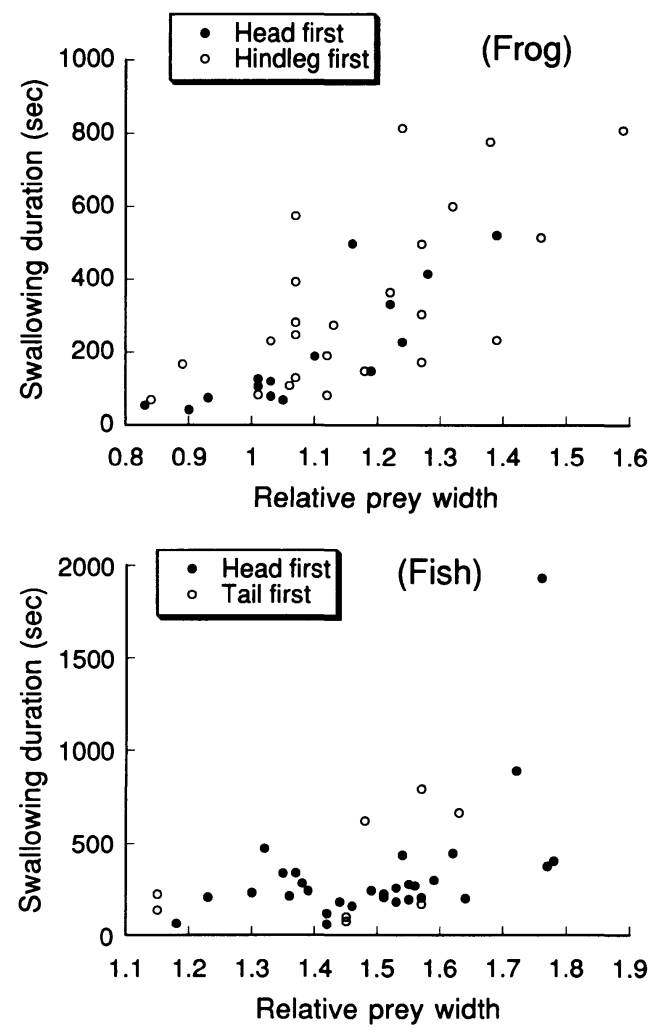

FIG. 1. Effects of direction of prey ingestion (head first or tail (hind legs) first) on swallowing duration of neonate Rhabdophis tigrinus feeding on frogs and fish. See Table 2 for the calculation of relative prey width. 


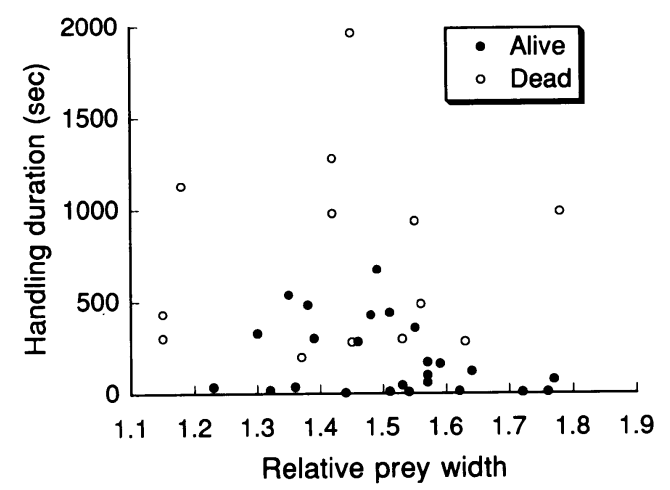

FIG. 2. Relationships between condition of prey at ingestion (alive or dead) and handling duration of neonate Rhabdophis tigrinus feeding on fish. See Table 2 for the calculation of relative prey width.

$\mathrm{F}=1.56, \mathrm{p}>0.2$ ). In fish trials, swallowing duration was significantly correlated with RPW in head first ingestion $(\mathrm{r}=0.49, \mathrm{dF}=28, \mathrm{t}=2.97$, $\mathrm{p}<0.01)$, but not in tail first ingestion $(\mathrm{dF}=6$, $t=1.50$, $p>0.15$; Fig. 1). There were no significant differences in either slopes or elevations between direction of ingestion of fish (ANCOVA; slopes, $\mathrm{dF}=1,34, \mathrm{~F}=0.14, \mathrm{p}>0.7$; elevations, $\mathrm{dF}=1,35, \mathrm{~F}=0.48, \mathrm{p}>0.45)$.

All frogs were swallowed alive. Approximately $40 \%$ of fish were swallowed dead. The RPW did not significantly affect condition of prey at ingestion in fish trials (live, $N=25, \bar{x}=1.51$, range $=1.23-1.77 ; \quad$ dead $, \quad \mathrm{N}=16, \quad \overline{\mathrm{x}}=1.47$, range $=1.15-1.81$; U-test, $\mathrm{z}=0.58, \mathrm{p}>0.5)$. There was no significant correlation between RPW and handling duration in either live or dead fish (live, $\mathrm{dF}=23, \mathrm{t}=-1.54, \mathrm{p}>0.1$; dead, $\mathrm{dF}=11, \mathrm{t}=0.26, \mathrm{p}>0.8$; Fig. 2). Dead fish were handled for a significantly longer duration than live ones (U-test, $\mathrm{z}=3.52, \mathrm{p}<0.001$ ).

Handling duration was not correlated with RPM in fish trials $(\mathrm{dF}=36, \mathrm{t}=-0.26, \mathrm{p}>0.75$; Fig. 3). In frog trials, handling duration was significantly correlated with RPM $(\mathrm{r}=0.59$, $\mathrm{dF}=38, \mathrm{t}=4.47, \mathrm{p}<0.001)$ : this correlation was, however, obviously caused by a single outlier (plotted at the far right in the upper figure of Fig. 3), and excluding this outlier resulted in no significant correlation between RPM and handling duration $(\mathrm{dF}=37, \mathrm{t}=-0.08, \mathrm{p}>0.9)$. Therefore, handling duration was compared between frog and fish trials using the U-test rather than ANCOVA. Fish were handled for a significantly longer duration than frogs (U-test, $\mathrm{z}=5.04, \mathrm{p}<0.001$ ). Swallowing duration was significantly correlated with RPM both in frog and fish trials (frog, $\mathrm{r}=0.71, \mathrm{dF}=38, \mathrm{t}=6.28$,
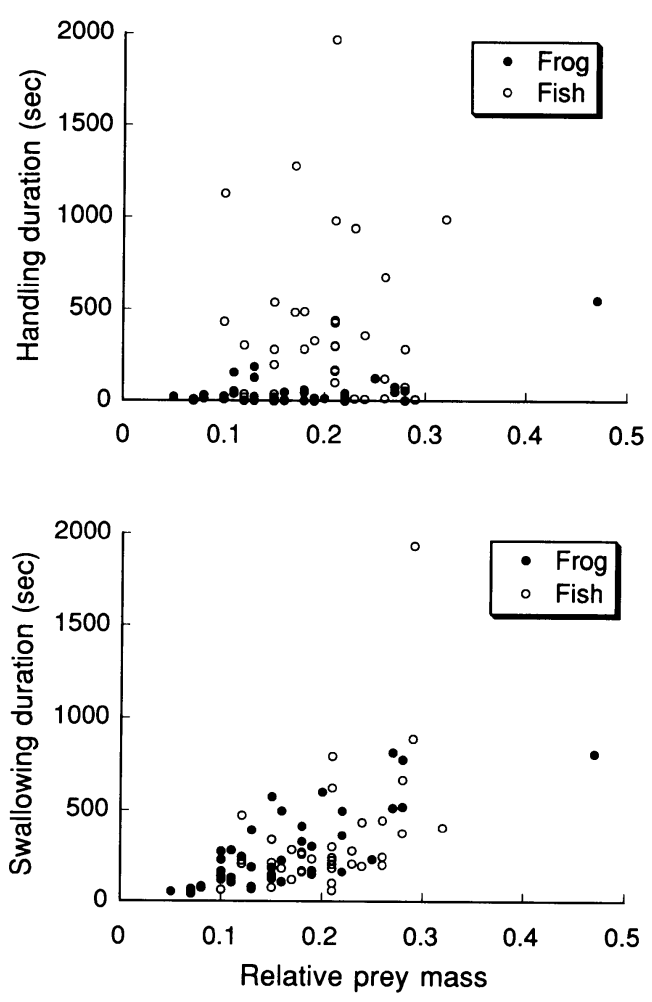

Fig. 3. Comparisons of swallowing and handling durations between frogs and fish in feeding tests of neonate Rhabdophis tigrinus. Relative prey mass was calculated as (body mass of prey)/(body mass of snake).

$\mathrm{p}<0.001 ;$ fish, $\mathrm{r}=0.51, \mathrm{dF}=36, \mathrm{t}=3.55$, $\mathrm{p}<0.005)$. There were no significant differences either in slopes or elevations between frog and fish trials (slopes, $\mathrm{dF}=1,76, \mathrm{~F}=0.15, \mathrm{p}>0.7$; elevations, $\mathrm{dF}=1,75, \mathrm{~F}=0.14, \mathrm{p}>0.7$ ).

\section{Discussion}

The following discussion should be preceded by a caveat and a plea. The caveat is that in this study I treated repeated measurements of the same subject as though they were independent of one another. The data pooling violates the assumption of independence of data for statistical analysis (see Martin and Bateson, 1993), and actual sample sizes were five and four for frog and fish trials, respectively, rather than 42 and 41 . Thus, caution is necessary to interpret the results. My plea is that graphical presentation and calculation of mean values do not necessarily require the assumption of the independence of data. Furthermore, overall difference in predatory behavior between frogs and fish seems apparent, and thus the difference 
may not be merely an artifact reproduced by pooling fallacy. I believe, therefore, that it is reasonable to make the following discussion based on the present data set.

Overall, $R$. tigrinus showed more efficient predatory behavior on frogs than on fish. Compared to frogs, fish were difficult to catch, frequently escaped during handling, and demanded much time to handle. Opportunistic underwater attack following open mouth searching has been reported as a characteristic of generalist fish eaters (Drummond, 1983). Frequent release or dropping of fish seemed to reflect inefficient maneuvering by jaw-walking (Mori, 1998). The superiority in handling frogs may be associated with the fact that, in nature, $R$. tigrinus mainly depends on frogs, and fish are additional food items. The snake may be more adapted for handling the main diet than occasional food items. Unlike some aquatic specialists such as homalopsine snakes, which usually handle and swallow fish underwater (Mori, 1998), $R$. tigrinus always handled and swallowed fish on land, also indicating less adaptation for an aquatic life, although the snake is generally considered semi-aquatic.

Preference for head first ingestion was observed only in fish feeding. Generally, it is considered that head first ingestion, especially of large prey, is an adaptation to minimize the resistance offered by the prey's appendages to reduce swallowing time (Diefenbach and Emslie, 1971; de Queiroz and de Queiroz, 1987). Then, why did the neonate $R$. tigrinus not show a preference for head first ingestion of large frogs?

There are, at least, three possible explanations. First, a tendency for head first ingestion of large prey may not be an innate property and may develop throughout the ontogeny. An innate preference for head first ingestion of large prey was demonstrated in some species of snakes (e.g., Thamnophis melanogaster, Enhydris plumbea, Cerberus rynchops, and Homalopsis buccata; Halloy and Burghardt, 1990; Mori, 1998), but not in others (e.g., T. butleri, T. radix, $T$. sirtalis, Elaphe dione, $E$. taeniura, $E$. climacophora, and E. quadrivirgata; Halloy and Burghardt, 1990; Mori, 1993, 1994). Whether the preference is innate or not partially depends on how the snakes specialize on a given food type: specialists tend to have an innate preference as an adaptive trait (Halloy and Burghardt, 1990; Mori, 1998). In this regard, $R$. tigrinus is an exceptional case because the diet of this species mostly consists of frogs. Second, the size of the frogs used in this experiment may not be large enough to elicit head first ingestion. However, in other species, head first ingestion is frequently observed within ranges of relative prey width similar to those of the present study (Halloy and Burghardt, 1990; Mori, 1991, 1994, 1995, 1996, 1998). Thus, this explanation may not be plausible. Third, head first ingestion may not be an essential feature for swallowing frogs. It is likely that the efficacy of head first ingestion is different among prey types. For instance, head first ingestion may be more advantageous when swallowing fish, because fish have many structures such as opercula, scales, and fin rays that might prevent or delay swallowing if swallowed tail first (Mori, 1998). This may explain why fish were preferably swallowed head first in $R$. tigrinus. Absence of difference in swallowing time between head first and hind legs first ingestion in frog trials may support the third explanation.

Many colubrid species have Duvernoy's glands with various degrees of development (Taub, 1967), and several biological functions have been proposed and demonstrated (e.g., Kardong, 1982; Hayes et al., 1993; RodríguezRobles, 1994). Toxicity of the secretions of $R$. tigrinus is extremely high (Sakai et al., 1983), although injecting mechanism of the secretions is not very efficient because of the posterior position of the enlarged maxillary teeth and the absence of anterior grooves on them. In this study approximately $40 \%$ of the fish died before swallowing, suggesting the function of killing or immobilizing prey. However, considering the fact that the fish were always handled on land, and that dead fish were handled longer than live ones, the death of the fish may have been mostly caused by suffocation rather than the toxic effects of the secretions. The absence of dead frogs also suggests the inefficiency of the secretions with regard to quickly killing prey. However, in the field, I have observed on several occasions large frogs or toads becoming weakened and bleeding during the prolonged handling by adult $R$. tigrinus and eventually dying during swallowing (Mori, unpublished data). More sophisticated experimental studies are necessary to elucidate the biological roles of the secretions of Duvernoy's glands in $R$. tigrinus.

ACKNOWLEDGMentS. - I am grateful to T. Hidaka for supporting this study. The research was partially supported by a Grant-in Aid for Special Project Research on "Biological Aspects of Optimal Strategy and Social Structure" from the Japan Ministry of Education, Science, and Culture. 


\section{Literature Cited}

De QueIroz, A. AND K. DE QueIroz. 1987. Prey handling behavior of Eumeces gilberti with comments on headfirst ingestion in squamates. J. Herpetol. 21: 57-63.

Diefenbach, C. O. and S. G. Emslie. 1971. Cues influencing the direction of prey ingestion of the Japanese snake, Elaphe climacophora (Colubridae, Serpentes). Herpetologica 27: 461-466.

DRUMMOND, H. 1983. Aquatic foraging in garter snakes: A comparison of specialists and generalists. Behaviour 86: 1-30.

FUKADA, H. 1959. Biological studies on the snakes. V. Food habits in the fields. Bull. Kyoto Gakugei Univ. Ser. B. 14: 22-28.

Hayes, W. K., P. Lavín-Murcio, and K. V. KarDONG. 1993. Delivery of Duvernoy's secretion into prey by the brown tree snake, Boiga irregularis (Serpentes: Colubridae). Toxicon 31: 881-887.

Halloy, M. and G. M. Burghardt. 1990. Ontogeny of fish capture and ingestion in four species of garter snakes (Thamnophis). Behaviour 112: 299-318.

KaDOWAKI, S. 1992. Food resource overlap between the two sympatric Japanese snakes (Elaphe quadrivirgata and Rhabdophis tigrinus) in the paddy fields. Jpn. J. Ecol. 42: 1-7. (in Japanese with English abstract)

KaRdONG, K. V. 1982. The evolution of the venom apparatus in snakes from colubrids to viperids \& elapids. Mem. Inst. Butantan 16: 105-118.

Martin, P. AND P. Bateson. 1993. Measuring Behaviour. An Introductory Guide. 2nd ed. Cambridge Univ. Press, Cambridge. 222 p.

MORI, A. 1991. Effects of prey size and type on preyhandling behavior in Elaphe quadrivirgata. J. Herpetol. 25(2): 160-166.

MORI, A. 1993. Prey handling behavior of neonatal rat snakes, Elaphe taeniura and E. dione (Colubridae). Jpn. J. Herpetol. 15(2): 59-63.

MORI, A. 1994. Prey handling behavior of newly hatched snakes in two species of the genus Elaphe with comparison to adult behavior. Ethology 97: 198-214.

MORI, A. 1995. Prey handling behavior of young rat snake, Elaphe taeniura (Squamata: Reptilia). Mem. Fac. Sci. Kyoto Univ. Ser. B. 16: 43-47.

MORI, A. 1996. A comparative study of the development of prey handling behavio in young rat snakes, Elaphe quadrivirgata and E. climacophora.
Herpetologica 52(3): 313-322.

MORI, A. 1998. Prey-handling behavior of three species of Homalopsine snakes (Colubridae): Features associated with piscivory and Duvernoy's glands. J. Herpetol. 32(1): in press.

MORIGUCHI, H. 1982. Appearance, movements and food habit of snakes at Minasegawa, Kanagawa, Japan. Snake, 14: 44-49. (in Japanese with English abstract)

MoRIGUCHI, H. 1996. Yamakagashi. In: S. Sengoku, T. Hikida, M. Matsui, and K. Nakaya (eds.), The Encyclopaedia of Animals in Japan, Vol. 8, Amphibians, Reptiles, Chondrichthyes. p. 89-91. Heibonsha, Tokyo. (in Japanese)

Moriguchi, H. AND S. NaIto. 1982. Activities and food habits of Amphiesma vibakari (Boie) and Rhabdophis tigrinus (Boie). Snake, 14: 136-142. (in Japanese with English abstract)

Rodríguez-Robles, J. A. 1994. Are the Duvernoy's gland secretions of colubrid snakes venom? J. Herpetol. 28: 388-390.

Siegel, S. and N. J. Castellan, Jr. 1988. Nonparametric Statistics for the Behavioral Sciences. McGraw-Hill, New York. 399 p.

Sakai, A., M. Honma, and Y. Sawai. 1983. Studies on the pathogenesis of envenomation of the Japanese colubrid snake, yamakagashi, Rhabdophis tigrinus tigrinus (Boie). 1. Study on the toxicity of the venom. Snake 15: 7-13.

SAS InSTITUTE Inc., 1989. SAS/STAT ${ }^{\circledR}$ User's Guide, Version 6, 4th Ed., Vol. 2. SAS Institute Inc., Cary. 846 p.

SoKal, R. R., AND F. J. RohlF. 1995. Biometry, 3rd Ed., W. H. Freeman and Company, New York. 887 p.

TAUB, A. M. 1967. Comparative histological studies on Duvernoy's gland of colubrid snakes. Bull. Am. Mus. Nat. Hist. 138: 1-50.

Toriba, M. AND Y. SAWAI. 1990. Venomous snakes of medical importance in Japan. In: P. Gopalakrishnakone and L. M. Chou (eds.), Snakes of Medical Importance (Asia-Pacific Region). p. 323-347. Venom and Toxic Research Group, Nat. Univ. Singapore and Internat. Soc. Toxicol., Singapore.

Department of Zoology, Graduate School of Science, Kyoto University, Sakyo, Kyoto, 60601 JAPAN 
要旨 ヤマカガシ（ヘビ亜目：ナミへビ科）卵障 化幼体におけるカエルおよびサカナに対 する捕食行動の比較

森哲

発達したデュベルノイ腺を持つへビであるヤ マカガシの捊化幼体に様々な大きさのカエルと サカナを飼育下で与兄, 慨の大きさやサイズが 捕食行動に及ぼす影響を調べた。カエルはサカ ナよりもたやすく捕獲され, 処理された. 吞及 込みの効率はカエルとサカナとで明瞭な違いは なかった、慨の相対的サイズは慨を吞み込む方 向と吞み込むときの慨の生死に影響しなかっ た、サカナは一部が死んでから吞まれ, 頭部か ら吞み込まれる傾向があった。これに対し，力 エルはすべて生さたまま吞まれ，吞み込む方向

に選好性はなかった。カエルにおいては，吞み 込む方向は最初に咬久ついた部位に依存する傾 向が強かったどちらの慨に拈いても，慨を吞 み込む方向は吞み込及時間に影響しなかった。 サカナの生死は処理時間の長さと関係している と考兄られた。 カェルを頭部から吞み込む傾向 がなかったことを除けば，ヤマカガン睬化幼体 はサカナよりもカエルの方がより効率良く捕食 できると考えられた。

（606-01 京都市左京区北白川追分町 京都大 学理学研究科動物学教室) 